\title{
Loneliness among migrants in Italy: risks and protectors
}

\begin{abstract}
In this study we focused on migrants' loneliness, in order to unpack risks and protective factors for loneliness among migrants in Italy. Our data come from the 'Social Condition and Integration among Foreign Citizens' survey conducted by ISTAT during 2011-2012 on a sample of 25,000 individuals living in a household with at least one foreign-born member. Our results show that economic resources and employment protect from loneliness feelings, whereas education does not. Family and social embeddedness and satisfaction with life are protective factors, whereas discrimination, language barriers, deprived neighbourhoods and poor health are associated with a higher risk of loneliness. Gender is a key lens to consider when analysing loneliness especially in relation to fragile populations like those with a migratory background.
\end{abstract}

\section{Keywords}

Loneliness, migration, Italy

\section{Introduction}

Loneliness is defined as a subjective experience of discrepancy between available and desired social relations, either in terms of quantity or quality (De Jong Gierveld, 1998). It is a negative assessment of own relationships because of unmet expectations. Weiss (1973) distinguishes between emotional and social loneliness, with the former related to intimate bonds like partner or best friend and the latter to embeddedness in broader social relations. Loneliness has negative impacts not only on individuals' lives but also on the society as a whole and is considered a public health issue because of its association with a wide range of health problems such as poor mental and physical health, depression, heart disease, alcohol and drug abuse, eating and sleeping disorders, higher mortality, etc. (Cacioppo et al., 2002; Cacioppo et al., 2006; Holwerda et al., 2012; Hawkley \& Cacioppo, 2010). Feelings of loneliness can appear in different life stages, due to life transitions such as the loss of loved ones, unemployment, divorce, migration. Previous research has shown that the younger and the older are at higher risk of loneliness (Cacioppo et al. 2006; Victor \& Yang, 2012).

Loneliness increases with age, in particular from 75 years onward (Dykstra et al., 2005) because this is a life stage where it is more likely to experience negative life events such as the loss of partner, friends and the deterioration in health (Dykstra \& De Jong Gierveld, 2004; Victor et al., 2005). Migration is another life event that has been demonstrated to trigger loneliness because of the disruption effects on family and social relations and hostile environments in the destination countries. Research on loneliness among ethnic groups focuses mainly on older migrants for whom the intersection of ageing and migration background causes a trap of vulnerabilities, increasing the likelihood of loneliness. Indeed, these studies show a positive relationship between being migrant and feeling lonely and a higher prevalence of loneliness among older migrants as compared to native peers for many reasons that range from low socio-economic conditions, poor health, bad housing conditions and deprived neighborhoods, unhealthy working conditions, language and cultural barriers, discrimination and hostility in the host country, homesickness (De Jong Gierveld et al., 2015; Dolberg Shiovitz-Ezra \& Ayalaon, 2016; Fokkema \& Naderi, 2013; Visser \& El Fakiri, 2016; Victor et al., 2012). There are other studies, however, that analyze ethnic groups as a whole without focusing 
specifically on older individuals (Visser \& El Fakiri, 2016). Although a flourishing body of literature has focused on migrants' loneliness at EU and extra EU level, to the best of our knowledge, no prior quantitative study has been carried out on this topic among migrants in Italy. In the present paper, we aim to fill this gap by analyzing, for the first time with a quantitative approach, loneliness among migrants in Italy. Our analyses are based on a unique dataset from a representative national survey conducted by ISTAT between 2011 and 2012, that specifically focus on migrants from different nationalities.

\section{Data and methods}

\subsection{Data source}

Our data come from the 'Social Condition and Integration among Foreign Citizens' survey conducted by ISTAT during 2011-2012 on a sample of 25,000 individuals living in a household with at least one foreign-born member. The two-stage sample design considers municipalities and households respectively as the first and second level units. The households are randomly selected from the Population Register (Anagrafe) that considers legal migrants only. All members of selected households are included in the sample and are interviewed through the CAPI technique.

The survey covers different topics regarding the migration experience and aspects of everyday life in Italy. For the purpose of our study, we consider migrants aged 18 years old or more for a total of 16,179 individuals.

\subsection{Variables and methods}

We used a logistic regression model with robust standard errors clustered by household. The dependent variable is the answer to a single item self-report loneliness rating question "Do you feel lonely?" that has been used in other previous studies (Victor et al., 2012). The response categories were 'never', 'sometimes', 'often' or 'always' lonely. We transformed it into a dummy variable (hereafter loneliness), coded 'Yes' if respondents rate themselves as sometimes or often lonely and 'No' (reference category) for the categories of never or rarely lonely.

We conducted the analysis for the whole sample (Table 3), and separately by gender (Table 4). For the whole model, we estimated several nested models adding one dimension per time, to check the effects of the different sets of independent variables on the likelihood of loneliness among migrants. Table 2 presents the descriptive statistics for the main structural variables.

\section{Independent variables}

Table 1 summarises the variables included in the models, that refer to six dimensions of analysis, and their categories.

We included four variables representing the socio-economic situation, namely educational level, perceived economic condition of the family the occupational status, and housing conditions.

Another set of variables is related to family relations represented by the presence and contacts with children, partner and parents.

We included the presence of intimate relations outside the family that represent a kind of emotional inclusiveness both in Italy and abroad. Another set of variables regards the presence/absence of individual barriers represented by fluency in Italian and societal barrier represented by discrimination which affects migrants' integration and inclusiveness into broader social relations. 
Table 1 -Description of independent and control variables

\begin{tabular}{|c|c|c|}
\hline \multicolumn{3}{|c|}{ Independent variables } \\
\hline $\begin{array}{l}\text { Dimension of } \\
\text { analysis }\end{array}$ & Variable & Categories and reference category \\
\hline \multirow{4}{*}{ Socio-economic } & Educational level & Compulsory (ref.); Secondary; Tertiary \\
\hline & $\begin{array}{l}\text { Perceived economic condition } \\
\text { of the family }\end{array}$ & Very bad/bad (ref.); Good/very good \\
\hline & Occupational status & $\begin{array}{l}\text { Employed (ref.); Unemployed; Housewife, } \\
\text { student, retired; Other }\end{array}$ \\
\hline & $\begin{array}{l}\text { Problems with the } \\
\text { accommodation (damp, small, } \\
\text {...) }\end{array}$ & No (ref.); Yes \\
\hline \multirow{3}{*}{ Family relations } & $\begin{array}{l}\text { Presence and contacts with } \\
\text { children }\end{array}$ & $\begin{array}{l}\text { All cohabiting children (ref.); Childless; } \\
\text { Some non-cohabiting and frequent contacts; } \\
\text { Some non-cohabiting and sporadic contacts; }\end{array}$ \\
\hline & $\begin{array}{l}\text { Presence and contacts with } \\
\text { partner }\end{array}$ & $\begin{array}{l}\text { Cohabiting partner (ref.); No partner; Frequent } \\
\text { contacts; Sporadic contacts }\end{array}$ \\
\hline & $\begin{array}{l}\text { Presence and contacts with } \\
\text { parents (separately mother and } \\
\text { father) }\end{array}$ & $\begin{array}{l}\text { Cohabiting mother/father (ref.); Deceased; } \\
\text { Frequent contacts; Sporadic contacts }\end{array}$ \\
\hline $\begin{array}{l}\text { Presence } r \text { of } \\
\text { intimate relations } \\
\text { outside the family }\end{array}$ & $\begin{array}{l}\text { Persons with whom } \\
\text { interviewees feel comfortable } \\
\text { to talk about private matters } \\
\text { (separately in Italy and abroad) }\end{array}$ & No (ref.); Yes \\
\hline \multirow{2}{*}{$\begin{array}{l}\text { Presence/absence } \\
\text { of individual and } \\
\text { societal barriers }\end{array}$} & Fluency in Italian & Yes (ref.); No \\
\hline & Discrimination & No (ref.); Yes \\
\hline \multirow{4}{*}{$\begin{array}{l}\text { Migrants' } \\
\text { participation in } \\
\text { outdoor activities }\end{array}$} & Participation in associations & No (ref.); Yes \\
\hline & Trust in others & $\begin{array}{l}\text { Most people can be trusted (ref.); You must be } \\
\text { careful in dealing with people }\end{array}$ \\
\hline & $\begin{array}{l}\text { Problems with the place of } \\
\text { residence related to quality and } \\
\text { safety }\end{array}$ & No (ref.); Yes \\
\hline & Importance of religion & Not important (ref.); Important \\
\hline \multirow{2}{*}{$\begin{array}{l}\text { Subjective } \\
\text { perceptions }\end{array}$} & Self-rated health & Fair/good/very good (ref.); Very bad/bad \\
\hline & Life satisfaction & Dissatisfied (ref.); Satisfied \\
\hline \multicolumn{3}{|c|}{ Control variable } \\
\hline \multicolumn{2}{|l|}{ Variable } & Categories and reference category \\
\hline \multicolumn{2}{|l|}{ Gender } & Male (ref.); Female \\
\hline \multicolumn{2}{|l|}{ Age } & (in years) \\
\hline \multicolumn{2}{|l|}{ Area of origin } & $\begin{array}{l}\text { Western migrants (ref.); Romania; Ukraine and } \\
\text { Moldova; Albania; Other Eastern Europe; } \\
\text { China; Philippines; Indian Subcontinent (India, } \\
\text { Pakistan, Sri Lanka and Bangladesh); Other } \\
\text { Asia; Morocco; Other North Africa; Sub- } \\
\text { Saharan Africa; Latin America }\end{array}$ \\
\hline \multicolumn{2}{|c|}{ Cohort of arrival in Italy } & $\begin{array}{l}\text { Before 1990s' (ref.); 1990-1994; 1995-1999; } \\
\text { 2000-2004; 2005-2012 }\end{array}$ \\
\hline
\end{tabular}




\begin{tabular}{|l|l|}
\hline Civil status & $\begin{array}{l}\text { Married (ref.); single; divorced or separated; } \\
\text { widow }\end{array}$ \\
\hline Macro area of residence in Italy & $\begin{array}{l}\text { North-West (ref.); North-East; Centre; South } \\
\text { and Islands }\end{array}$ \\
\hline
\end{tabular}

To capture the role of migrants' participation in outdoor activities, we included four variables: participation in associations; trust in others; problems with the place of residence related to quality and safety; and the importance of religion as a proxy of attending religious services.

The last set of variables is related to subjective perceptions: self-rated health and life satisfaction.

\section{Control variables}

We included six control variables: gender, age and age squared, area of origin, cohort of arrival in Italy, civil status and macro area of residence.

\section{Results}

Descriptive results (Table 2) show that $15.44 \%$ of migrants feel lonely. Females are more likely to feel lonely compared to males and this is confirmed also by our models.

The majority of respondents are women, married, coming from East Europe, after the year 2000, with a coresident partner and some or all coresident children, resident in the Northern regions. Usurpingly, women arrived more recently compared to men, and they have more frequently coresident children and partner.

The more recent cohort of migrants, namely those arrived in Italy from 2005 and 2012 show a higher likelihood of loneliness compared to long-term migrants, but this difference become weaker when we take into account personal and societal barriers, and more precisely language difficulties and discrimination. Migrants from Asia and Africa are more likely to feel lonely compared to migrants coming from Western countries. Also, those coming from Ukraine and Moldova have a higher likelihood of loneliness, but the effect become weaker when considering aspects related to subjective perceptions.

Table 2 - Descriptive statistics by gender

\begin{tabular}{|c|c|c|c|}
\hline Variable & $\begin{array}{l}\% \text { total } \\
\text { sample }\end{array}$ & $\%$ Male & $\%$ Female \\
\hline Feeling lonely & 15.44 & 14.94 & 15.85 \\
\hline Female & 54.74 & & \\
\hline \multicolumn{4}{|l|}{ Cohort of arrival in Italy } \\
\hline before 1990s' & 6.40 & 8.58 & 4.61 \\
\hline 1990-1994 & 8.46 & 10.67 & 6.64 \\
\hline 1995-1999 & 15.80 & 17.67 & 14.26 \\
\hline $2000-2004$ & 35.37 & 33.00 & 37.33 \\
\hline $2005-2012$ & 33.96 & 30.09 & 37.15 \\
\hline \multicolumn{4}{|l|}{ Area of origin } \\
\hline Romania & 21.53 & 20.20 & 22.63 \\
\hline Ukraine and Moldova & 7.99 & 3.45 & 11.74 \\
\hline
\end{tabular}




\begin{tabular}{|r|c|c|c|}
\hline Albania & 10.07 & 12.11 & 8.37 \\
\hline Other East Europe & 9.17 & 7.32 & 10.70 \\
\hline China & 3.75 & 4.21 & 3.37 \\
\hline Philippines & 2.89 & 2.80 & 2.97 \\
\hline India, Pakistan, Bangladesh and Sri Lanka & 7.17 & 9.57 & 5.19 \\
\hline Other Asia & 1.97 & 1.86 & 2.05 \\
\hline Morocco & 9.70 & 11.88 & 7.90 \\
\hline Other North Africa & 4.47 & 6.86 & 2.50 \\
\hline Sub-Saharan Africa & 6.14 & 7.42 & 5.08 \\
\hline Latin America & 8.64 & 6.63 & 10.31 \\
\hline Western Migrants & 6.51 & 5.69 & 7.19 \\
\hline & & & \\
\hline Nacro area of residence & & 36.33 & 33.97 \\
\hline North-West & 35.04 & 27.00 & 26.37 \\
\hline Centre & 24.32 & 23.54 & 24.97 \\
\hline Cohabitant partner & 26.66 & 13.12 & 14.69 \\
\hline Cohabitant children & 58.66 & 55.35 & 61.40 \\
\hline
\end{tabular}

Source: Own elaboration on SCIF survey.

Educational level has a strong positive association with loneliness, the higher the education, the higher the likelihood of feeling lonely, whereas the other two aspects of socio-economic conditions, namely economic resources and employment conditions have an inverse relation with loneliness; a positive assessment over family's economic condition and the condition of being employed are negatively associated with loneliness. Close family contacts also have a key role; the presence of a partner is crucial in this relation and its absence or sporadic contacts with him/her have a positive and strong effect on loneliness. As for the presence of children, migrants with non-cohabitant children but frequent contacts with them are more likely to feel lonely compared to those migrants with all coresident children. As for the relationships with parents, those migrants who declare to co-reside with the mother feel less lonely compared to those who have lost their mother or have sporadic contacts with her. Intimate relations outside the family do have an important effect on loneliness as well; those who have friends in Italy on whom they can rely on for intimate matters are more likely to be protected from loneliness whereas the presence of intimate relations abroad is a risk factor. Those who have experienced discrimination are more likely to feel lonely compared to those who have not been discriminated, whereas having difficulties with the Italian language has a positive effect on loneliness feeling. Lack of general trust towards other people is positively related to loneliness too. The association between loneliness and the last two independent variables, related to subjective perceptions have opposite directions: bad health is positively related to loneliness while life satisfaction negatively.

Table 3 - Results of logistic regression models: OR and significance.

\begin{tabular}{|r|c|c|c|c|c|c|}
\hline \multirow{2}{*}{ Variable } & Model 1.1 & Model 1.2 & Model 1.3 & Model 1.4 & Model 1.5 & Model 1.6 \\
\cline { 2 - 7 } & OR & OR & OR & OR & OR & OR \\
\hline $\begin{array}{l}\text { Educational level (ref. None } \\
\text { or primary) }\end{array}$ & & & & & & \\
\hline Secondary & 0.949 & 1.028 & 1.048 & 1.118 & 1.135 & 1.153 \\
\hline Tertiary & 1.127 & $1.313^{*}$ & 1.307 & $1.424^{*}$ & $1.518^{* *}$ & $1.521^{* *}$ \\
\hline
\end{tabular}




\begin{tabular}{|c|c|c|c|c|c|c|}
\hline $\begin{array}{l}\text { Perceived economic } \\
\text { condition of the family } \\
\text { good/very good (ref. Very } \\
\text { bad/bad) }\end{array}$ & $0.668 * * *$ & $0.650 * * *$ & $0.650 * * *$ & $0.666^{* * *}$ & $0.691 * * *$ & $0.814^{*}$ \\
\hline \multicolumn{7}{|l|}{$\begin{array}{l}\text { Occupational status (ref. } \\
\text { Employed) }\end{array}$} \\
\hline Unemployed & $1.288^{*}$ & $1.532 * * *$ & $1.491 * * *$ & $1.451 * * *$ & $1.432 * * *$ & $1.236^{*}$ \\
\hline Housewife, student, retired & $0.804 *$ & 1.113 & 1.097 & 1.029 & 1.021 & 1.033 \\
\hline other & 0.986 & 1.153 & 1.111 & 1.039 & 1.058 & 0.937 \\
\hline $\begin{array}{l}\text { Problems with the } \\
\text { accommodation (ref. No) }\end{array}$ & $1.358 * * *$ & $1.431 * * *$ & $1.433 * * *$ & $1.390 * * *$ & $1.386^{* * *}$ & $1.302 * * *$ \\
\hline \multicolumn{7}{|l|}{$\begin{array}{l}\text { Presence and contacts with } \\
\text { children (ref. All cohabitant } \\
\text { children) }\end{array}$} \\
\hline Childless & & 1.075 & 1.049 & 1.049 & 1.064 & 1.045 \\
\hline $\begin{array}{r}\text { Some non-cohabitant } \\
\text { children frequent contacts }\end{array}$ & & $1.520 * * *$ & $1.505 * * *$ & $1.505 * * *$ & $1.496 * * *$ & $1.490 * * *$ \\
\hline $\begin{array}{r}\text { Some non-cohabitant } \\
\text { children sporadic contacts }\end{array}$ & & 1.268 & 1.206 & 1.226 & 1.258 & 1.179 \\
\hline \multicolumn{7}{|l|}{$\begin{array}{l}\text { Presence and contacts with } \\
\text { partner (ref. Cohabitant } \\
\text { partner) }\end{array}$} \\
\hline No partner & & $2.402 * * *$ & $2.250 * * *$ & $2.250 * * *$ & $2.244 * * *$ & $2.170 * * *$ \\
\hline Frequent contacts & & 1.140 & 1.112 & 1.111 & 1.095 & 1.043 \\
\hline Sporadic contacts & & $4.842 * * *$ & $3.928 * * *$ & $4.015 * * *$ & $4.121 * * *$ & $4.034 * * *$ \\
\hline \multicolumn{7}{|l|}{$\begin{array}{l}\text { Presence and contacts with } \\
\text { father (ref. cohabitant) }\end{array}$} \\
\hline Deceased & & 1.355 & 1.361 & 1.301 & 1.285 & 1.194 \\
\hline Frequent & & 0.921 & 0.980 & 0.950 & 0.957 & 0.905 \\
\hline Sporadic & & 1.314 & 1.307 & 1.259 & 1.245 & 1.178 \\
\hline \multicolumn{7}{|l|}{$\begin{array}{l}\text { Presence and contacts with } \\
\text { mother (ref. cohabitant) }\end{array}$} \\
\hline Deceased & & $1.959 * * *$ & $1.717^{* *}$ & $1.692 * *$ & $1.728^{* *}$ & $1.663 * *$ \\
\hline Frequent & & 1.231 & 1.199 & 1.151 & 1.164 & 1.146 \\
\hline Sporadic & & $2.185 * * *$ & $1.848 * * *$ & $1.815 * * *$ & $1.869 * * *$ & $1.828 * * *$ \\
\hline $\begin{array}{l}\text { Having persons with whom } \\
\text { interviewees feel } \\
\text { comfortable to talk about } \\
\text { private matters in Italy (ref. } \\
\text { No) }\end{array}$ & & & $0.426 * * *$ & $0.428 * * *$ & $0.428 * * *$ & $0.460 * * *$ \\
\hline $\begin{array}{l}\text { Having persons with whom } \\
\text { interviewees feel } \\
\text { comfortable to talk about } \\
\text { private matters abroad (ref. } \\
\text { No) }\end{array}$ & & & $1.664 * * *$ & $1.650 * * *$ & $1.657 * * *$ & $1.635^{* * *}$ \\
\hline Discrimination (ref. No) & & & & $1.536^{* * *}$ & $1.535^{* * *}$ & $1.414 * * *$ \\
\hline $\begin{array}{l}\text { Non fluent in Italian (ref. } \\
\text { Fluent) }\end{array}$ & & & & $1.554 * * *$ & $1.525 * * *$ & $1.470 * * *$ \\
\hline $\begin{array}{l}\text { Participation in associations } \\
\text { (ref. No) }\end{array}$ & & & & & 0.817 & 0.837 \\
\hline $\begin{array}{l}\text { You must be careful in } \\
\text { dealing with people (ref. } \\
\text { trust in other) }\end{array}$ & & & & & $1.730 * * *$ & $1.649 * * *$ \\
\hline
\end{tabular}




\begin{tabular}{|l|l|l|l|l|l|l|}
\hline $\begin{array}{l}\text { Problems with the place of } \\
\text { residence related to quality } \\
\text { and safety (ref. No) }\end{array}$ & & & & & 1.239 & $1.288^{*}$ \\
\hline $\begin{array}{l}\text { Religion is important (ref. } \\
\text { non important) }\end{array}$ & & & & & 1.033 & 1.149 \\
\hline $\begin{array}{l}\text { Bad/very bad health (ref. } \\
\text { good/very good) }\end{array}$ & & & & & & $1.427^{* * *}$ \\
\hline Satisfied (ref. dissatisfied) & & & & & & $0.373^{* * *}$ \\
\hline Pseudo R2 & 0.051 & 0.097 & 0.111 & 0.120 & 0.127 & 0.152 \\
\hline
\end{tabular}

Source: Own elaborations on SCIF survey.

Note: The model controls for age, age squared, gender, area of origin, cohort of arrival in Italy, civil status and macro area of residence.

Legend: $* p<0.05 ; * * p<0.01 ; * * * p<0.001$

When we run the analysis separately for men and women (Table 4) several differences emerge confirming the importance of considering gender as a key variable when interpreting results on loneliness. We should pay attention however when interpreting these gender differences because of different positions in the literature regarding the comparability of odds ratios across groups (Buis, 2017; Mood, 2010; Williams, 2009). A striking difference is the role of good perceived economic resources on the likelihood of feeling lonely, that has a clear direction (protective) only for men. Likewise, also higher education is positively associated with loneliness only for men. Whereas unemployment results in a risk factor only for women. Family contacts, with children and mother, have an influence on loneliness for women only; in particular, those women who have non-coresident children and have a deceased mother or occasional contacts with her are more likely to feel lonely compared to women with coresident children and alive mother. Not having experienced discrimination and participation in associations protects from loneliness women only.

Table 4 - Results of the full logistic regression model by gender: OR and significance

\begin{tabular}{|c|c|c|}
\hline & Male & Female \\
\hline Variable & OR & OR \\
\hline \multicolumn{3}{|l|}{ Educational level (ref. None or primary) } \\
\hline Secondary & 1.334 & 1.021 \\
\hline Tertiary & $1.868^{*}$ & 1.316 \\
\hline $\begin{array}{l}\text { Perceived economic condition of the family } \\
\text { good/very good (ref. Very bad/bad) }\end{array}$ & $0.684 * *$ & 0.934 \\
\hline \multicolumn{3}{|l|}{ Occupational status (ref.= Employed) } \\
\hline Unemployed & 1.057 & $1.501 * *$ \\
\hline Housewife, student, retired & 0.805 & 1.057 \\
\hline other & 1.347 & $0.633^{*}$ \\
\hline Problems with the accommodation (ref. $=$ No) & $1.289^{*}$ & $1.294 * *$ \\
\hline \multicolumn{3}{|l|}{$\begin{array}{l}\text { Presence and contacts with children (ref. All } \\
\text { cohabitant children) }\end{array}$} \\
\hline Childless & 0.788 & 1.209 \\
\hline Some non-cohabitant children frequent contacts & 1.392 & $1.435 * *$ \\
\hline Some non-cohabitant children sporadic contacts & 0.958 & 1.308 \\
\hline \multicolumn{3}{|l|}{$\begin{array}{l}\text { Presence and contacts with partner (ref. Cohabitant } \\
\text { partner) }\end{array}$} \\
\hline No partner & $2.476^{* *}$ & $2.232 * * *$ \\
\hline Frequent contacts & 0.509 & 1.547 \\
\hline Sporadic contacts & $4.972 * * *$ & $3.206^{* * *}$ \\
\hline
\end{tabular}




\begin{tabular}{|c|c|c|}
\hline \multicolumn{3}{|l|}{$\begin{array}{l}\text { Presence and contacts with father (ref. }= \\
\text { cohabitant) }\end{array}$} \\
\hline Deceased & 1.158 & 1.156 \\
\hline Frequent & 0.847 & 0.883 \\
\hline Sporadic & 1.231 & 1.057 \\
\hline \multicolumn{3}{|l|}{$\begin{array}{l}\text { Presence and contacts with mother } \\
\text { (ref.=cohabitant) }\end{array}$} \\
\hline Deceased & 1.309 & $2.108 * *$ \\
\hline Frequent & 1.334 & 1.053 \\
\hline Sporadic & 1.627 & $2.155 * *$ \\
\hline $\begin{array}{l}\text { Having persons with whom interviewees feel } \\
\text { comfortable to talk about private matters in Italy } \\
\text { (ref.= No) }\end{array}$ & $0.437 * * *$ & $0.482 * * *$ \\
\hline $\begin{array}{l}\text { Having persons with whom interviewees feel } \\
\text { comfortable to talk about private matters abroad } \\
\text { (ref.= No) }\end{array}$ & $1.999 * * *$ & $1.406^{* *}$ \\
\hline Discrimination $(\mathrm{ref} .=\mathrm{No})$ & 1.296 & $1.558 * * *$ \\
\hline Non fluent in Italian (ref.= Fluent) & $1.440 *$ & $1.489 * *$ \\
\hline Participation in associations (ref. $=$ No) & 0.977 & $0.639^{*}$ \\
\hline $\begin{array}{l}\text { You must be careful in dealing with people (ref.= } \\
\text { trust in other) }\end{array}$ & $1.598^{* * *}$ & $1.678 * * *$ \\
\hline $\begin{array}{l}\text { Problems with the place of residence related to } \\
\text { quality and safety (ref.= No) }\end{array}$ & 1.313 & 1.312 \\
\hline Religion is important (ref. $=$ non important) & 1.199 & 1.101 \\
\hline Bad/very bad health (ref.= good/very good) & $1.367 *$ & $1.460 * * *$ \\
\hline Satisfied (ref.= unsatisfied) & $0.380 * * *$ & $0.363 * * *$ \\
\hline Pseudo R2 & 0.203 & 0.128 \\
\hline
\end{tabular}

Source: Own elaboration on SCIF survey.

Note: The model controls for age, age squared, gender, area of origin, cohort of arrival in Italy, civil status and macro area of residence.

Legend: $* p<0.05 ; * * p<0.01 ; * * * p<0.001$

\section{Discussion}

In this study, we analyzed risks and protectors of loneliness among migrants in Italy, using a unique dataset from a survey conducted by ISTAT during 2011-2012. To the best of our knowledge, this paper presents the first quantitative study on migrants' loneliness in Italy. Overall, our results show that socio-economic conditions have an important role on loneliness feelings; in particular employment and a positive assessment of economic resources negatively correlate with loneliness which is in line with previous findings showing that higher socio-economic status means more financial resources and thus possibilities to have a wider social network and participate to outdoor activities (Antonucci et al., 1999; Fokkema \& Naderi, 2013). Contrary to previous studies, education does not protect from loneliness. This result might be country-specific as migrants in Italy are negatively selected concerning education, so it might be that those who have a higher education represent a small pool of individuals and this might jeopardise their opportunities to hang out with co-ethnic peers with similar backgrounds and interests (Authors, 2017).

In line with previous finding, our results show that social embeddedness within the close family is a protective factor against loneliness (Fokkema \& Naderi, 2013; van den Broek \& Grundy, 2017). Indeed, lack of contacts with the immediate family like children, partner and own parents, in particular mother (because children, for example, are not all residing with parents, absence of partner and mother or rare contacts with them), is strongly intertwined with loneliness. This is not surprising, 
as in migrant families multigenerational households are more common, and co-residence and proximity mean mutual support and informal care exchange, that in a context of migration are crucial (de Jong Gierveld et al., 2012; de Valk \& Schans, 2008).

Likewise, social resources outside the domestic walls have a key role in increasing the risk of loneliness when they are lacking. Our results show that societal barriers to inclusion, such as discrimination, represent a strong risk factor in increasing loneliness feelings among migrants. If we add to this language barriers and living in deprived neighbourhoods (Scharf \& de Jong Gierveld, 2008), which are quite common situations for migrants, then social exclusion and loneliness are the expected results. Moreover, distrustful societies spread distrust also among migrants and are highly likely to transform their disadvantages into an escalation of negative feelings towards society, increasing their sense of exclusion and loneliness. Another relevant ingredient of loneliness is health. In line with the empirical literature (Mladovsky, 2007), our results show that poor health is associated with a higher risk of loneliness. This is a crucial aspect to take into consideration, as we know from previous studies that, although health conditions represent a prerequisite of social relations for both migrants and natives (Hawkley \& Cacioppo, 2010), migrants are more likely to report poor health status compared to the native population (Authors, 2019; Loi \& Hale, 2019). And we know also that, despite the initial health advantage of migrants when they arrive in Western countries - known as 'healthy migrant effect', (Borjas, 1987) - as time goes by there is an accumulation of disadvantages which translate into a deterioration over time and generations of their health status -the 'exhausted migrant effect', Bollini and Siem (1995).

Overall, migrants who are more satisfied with life are also less likely to feel lonely. Our results show that gender is a key lens to take into consideration when analysing determinants of loneliness. Indeed, for men, good economic conditions represent an important protective factor against loneliness, whereas for women protective factors are more related to social relations both within and outside the family. In particular, co-residence with children and mother, participation in associations and lack of discrimination reduce the risk of feeling lonely. In addition, unemployment is associated with loneliness for women only, probably because employment represents for many of them the main exist channel from the domestic walls.

Our study has some limitations as well related to the characteristics of the SCIF dataset. Loneliness is a quite new topic among migration scholars in Italy, so information (for example related to support given and received, embeddedness within the family and living arrangements) that would have been helpful for our analysis is missing in the data. Moreover, the cross-sectional nature of the data prevents us from analysing loneliness in a life course perspective.

Despite these limitations, our study makes an important contribution to the existing research on the potential risk factors of loneliness which, from a preventive point of view and a public health perspective, are essential to acknowledge given its association with mortality and a wide range of poor health outcomes and behaviours (Victor et al., 2012), and because the intersection of the migratory background and the process of 'ageing in place' might transform into a multiple trap of vulnerabilities for the migrant population. 


\section{References}

Antonucci, T.C., Ajrouch, K.J., and Janevic, M. (1999). "Socioeconomic status, social support, age, and health". Annals of the New York Academy of Sciences, 896(1):390-392. https://deepblue.lib.umich.edu/bitstream/handle/2027.42/74549/j.1749-

6632.1999.tb08150.x.pdf; sequence=1

Authors (2019).

Authors (2017).

Bollini, P., and Sim, H. (1995). "No Real Progress Towards Equity: Health of Migrants and Ethnic Minorities on the eve of the Year 2000". Social Science and Medicine, 41(6): 819-828. DOI: $\underline{10.1016 / 0277-9536(94) 00386-8}$

Borjas, G. (1987). "Self-selection and the Earnings of Immigrants". American Economic Review, 77 (4): 531-553.

Buis, M. L. (2017). "Logistic regression: When can we do what we think we can do?" http://maartenbuis.nl/wp/odds_ratio_3.1.pdf, Accessed 19th of February 2020.

Cacioppo, J.T., Hawkley, L.C., Crawford, L. E., Ernst, J. M., Burleson, M. H., Kowalewski, R. B., Malarkey, W. B., Van Cauter, E, and Berntson, G.G. (2002). "Loneliness and health: Potential mechanisms". Psychosomatic Medicine, 64(3): 407-417. DOI: 10.1097/00006842-200205000-00005

Cacioppo, J.T., Hughes, M.E., Waite, L.J., Hawkley, L.C., and Thisted, R.A. (2006). "Loneliness as a specific risk factor for depressive symptoms: cross-sectional and longitudinal analyses". 
Psychology and Aging, 21(1): 140-151. DOI: 10.1037/0882-7974.21.1.140

de Jong Gierveld, J. (1998). “A review of loneliness: concept and definitions, determinants and consequences". Reviews in Clinical Gerontology, 8(1): 73-80. DOI: 10.1017/S0959259898008090

de Jong Gierveld, J., Dykstra, P.A., and Schenk, N. (2012). "Living arrangements, intergenerational support types and older adult loneliness in Eastern and Western Europe". Demographic Research, 27:167-200. https://www.demographic-research.org/volumes/vol27/7/27-7.pdf

de Jong Gierveld, J., Van der Pas, S., and Keating, N. (2015). “Loneliness of Older Immigrant Groups in Canada: Effects of Ethnic-Cultural Background”. Journal of Cross Cultural Gerontology, 30(3): 251-68. DOI: 10.1007/s10823-015-9265-X

de Valk H., and Schans, D. (2008). “"They ought to do this for their parents': perceptions of filial obligations among immigrant and Dutch older people”. Ageing Society, 28(1): 49-66. DOI: $\underline{10.1017 / \mathrm{S} 0144686 \times 07006307}$

Dolberg, P., Shiovitz-Ezra, S., and Ayalon, L. (2016). "Migration and changes in loneliness over a 4year period: the case of older former Soviet Union immigrants in Israel". European Journal of Ageing, 13(4): 287-297. https://www.ncbi.nlm.nih.gov/pmc/articles/PMC5550612/

Dykstra, P.A., van Tilburg, T.G., and de Jong Gierveld, J. (2005). "Changes in Older Adult Loneliness: Results from a Seven-Year Longitudinal Study”. Research on Aging, 27(6): 725-747. DOI: $\underline{10.1177 / 0164027505279712}$ 
Dykstra, P.A., and de Jong Gierveld, J. (2004). “Gender and Marital-History Differences in Emotional and Social Loneliness Among Dutch Older Adults". Canadian Journal on Aging/La revue canadienne du vieillissement, 23:141-55. DOI: $10.1353 /$ cja.2004.0018

Fokkema, T., and Naderi, R. (2013). "Differences in late-life loneliness: a comparison between Turkish and native-born older adults in Germany". European Journal of Ageing, 10(4): 289-300. DOI: $10.1007 / \mathrm{s} 10433-013-0267-7$

Hawkley, L.C., and Cacioppo, J.T. (2010). "Loneliness matters: a theoretical and empirical review of consequences and mechanisms". Annals of Behavioral Medicine, 40(2):218-227. DOI: $10.1007 / \mathrm{s} 12160-010-9210-8$

Holwerda, T.J., Beekman, A.T., Deeg, D.J., Stek, M.L., van Tilburg, T.G., Visser, P.J., Schmand, B., Jonker, C., and Schoevers, R.A. (2012). "Increased risk of mortality associated with social isolation in older men: only when feeling lonely? Results from the Amsterdam Study of the Elderly (AMSTEL)". Psychological Medicine, 42(4): 843-853. DOI: 10.1017/S0033291711001772

Loi, S., and Hale, J.M. (2019). "Migrant Health Convergence and the Role of Material Deprivation”. Demographic Research, 40(32): 934-958. https://www.demographicresearch.org/volumes/vol40/32/40-32.pdf

Mladovsky, P. (2007). "Migrant Health in the EU”. Eurohealth, 13(1): 9-11. https://www.euro.who.int/_data/assets/pdf_file/0008/80468/Eurohealth13_1.pdf\#page=12

Mood, C. (2010). "Logistic regression: Why we cannot do what we think we can do, and what we can do about it". European Sociological Review, 26(1): 67-82. 
https://pdfs.semanticscholar.org/fce4/c99418bd27ec416a274d25ce898b4b576b46.pdf?.ga=2.79740

\section{$\underline{311.1475584360 .1610105753-1549812405.1610105753}$}

Scharf, T., and de Jong Gierveld, J. (2008). "Loneliness in urban neighbourhoods: an Anglo-Dutch comparison”. European Journal of Ageing, 5(2):103-115.

Van den Broek, T., and Grundy, E. (2017). "Loneliness among Polish migrants in the Netherlands:

The impact of presence and location of partners and offspring". Demographic Research, 37: 727-

742. https://www.demographic-research.org/volumes/vol37/23/37-23.pdf

Victor, C.R., Scambler, S.J., Bowling, A., and Bond, J. (2005). "The prevalence of, and risk factors for, loneliness in later life: a survey of older people in Great Britain”. Ageing and Society, 25: 357375. DOI: $10.1017 / \mathrm{S} 0144686 \mathrm{X} 04003332$

Victor, C. R., Burholt, V., and Martin, W. (2012). "Loneliness and ethnic minority elders in Great Britain: an exploratory study”. Journal of Cross Cultural Gerontology, 27(1):65-78. DOI:

$\underline{10.1007 / \mathrm{s} 10823-012-9161-6}$

Victor, C. R., and Yang, K. (2012). "The Prevalence of Loneliness Among Adults: A Case Study of the United Kingdom”. The Journal of Psychology, 146(1-2): 85-104. DOI:

$\underline{10.1080 / 00223980.2011 .613875}$

Visser, M.A., and El Fakiri, F. (2016). "The prevalence and impact of risk factors for ethnic differences in loneliness". The European Journal of Public Health, 26(6): 977-983. https://www.ncbi.nlm.nih.gov/pmc/articles/PMC5172492/ 
Weiss RS. (1973). Loneliness: The experience of emotional and social isolation. Cambridge, MA: MIT Press.

Williams, R. (2009). “Comparing Logit and Probit coefficients Across Groups”. Sociological Methods and Research, 37(4): 531-559. DOI: 10.1177/0049124199028002003 